\title{
School Counseling: An Evolving Specialty
}

By Pamela O. Paisley, L. DiAnne Borders

This is the pre-peer reviewed version of the following article: Paisley, P. O., \& Borders, L. D. (1995). School counseling: An evolving specialty. Journal of Counseling and Development, 74(2), 150-153, which has been published in final form at http://search.proquest.com/docview/219008799?accountid=14604.

\section{Abstract:}

A review of school counseling as a specialty area of the counseling profession is provided, including attention to historical development, training standards and accreditation, certification and future trends and issues.

Keywords: School Counseling | Education | Trends | History

\section{Article:}

School counseling as a specialty area of the counseling profession emerged, and continues to evolve, as a result of social, educational, political, and economic trends. Specifically, at the beginning of the twentieth century, divergent needs of public school populations required the inclusion of specialized assistance for students beyond that which was commonly and previously offered by teachers (Schmidt, 1993). The need for such specialized assistance for students remains apparent today. Demographic information (Glosoff \& Koprowicz, 1990; Hodgkinson, 1985) describes a context for children and adolescents that includes divorce, poverty, violence, and neglect as well as the anticipated transitions associated with the process of growing up.

\section{HISTORICAL DEVELOPMENT OF THE SPECIALTY}

The first school guidance programs appeared in the late 1800s and were closely connected to vocational education. Early programs were directive in nature and involved the provision of guidance classes to promote character development, teach socially appropriate behaviors, and assist with vocational planning. Reviews of the historical development of this specialty (e.g., Baker, 1992; Schmidt, 1993; Wittmer, 1993) indicate that the scope and focus of school counseling programs changed over time: from vocational and educational decision making, to personal growth, to responsive services for special "at-risk" populations, to developmental programs available for all students.

The focus has changed in response to a number of factors. While some of these influences were significant for the entire counseling profession (e.g., the Industrial Revolution, placement efforts by the military, the work of individuals such as Frank Parsons and Carl Rogers), other factors have had a more direct impact on the evolution of school counseling.

Influence of Federal Legislation 
Federal legislation has been particularly significant in the creation and definition of counseling positions in public schools. The National Defense Education Act in 1958 and the Elementary and Secondary Education Act in 1965 provided particular opportunities for training school counselors and implementing specialized programs. Depending on the focus of the legislation, these programs provided services for vocationally oriented and college-bound students, school dropouts, and economically and academically disadvantaged young people (Minkoff \& Terres, 1985). Legislation continues to influence the focus of this specialty area, as most recently evident in the potential effects of the School-to-Work Opportunities Act (1994) and the Elementary School Counseling Demonstration Act (1995).

Influence of Professional Associations

The creation of a professional association specifically for school counselors also contributed greatly to the development of the specialty. Although not one of the founding divisions of the American Personnel and Guidance Association, the American School Counselor Association (ASCA) became the fifth division in 1953 (Minkoff \& Terres, 1995). Through discussion, debate, and publication of role statements, position papers, and ethical standards, this division has been very influential in the direction and shape of school counseling as it is known today.

The Association for Counselor Education and Supervision (ACES) and the National Career Development Association (NCDA) have also had a special interest in this area. ACES has sponsored program sessions, special roundtable discussions, an interest network, and collaborative efforts related to school counseling. NCDA members have supported federal legislation focused on school-to-work transition and have helped maintain a focus on school counselor involvement in career education, development, and planning for students.

In the past 15 years, several specific projects have been sponsored by these professional associations to consider the future of this specialty area and to address school counseling concerns. Examples of these special efforts can be seen in the following: (a) specific position statements adopted by ASCA (American School Counselor Association, 1981, 1984, 1985), (b) "think tanks" supported by the American Counseling Association (ACA), (c) ACES School Counseling Interest Networks at the regional and national level, (d) the Southern Association for Counselor Education and Supervision Roundtable on School Counseling Preparation Programs, (e) the 20/20 Conference cosponsored by ACA and the Educational Resources Information Center/Counseling and Personnel Services Clearinghouse (ERIC/ CAPS), and (f) establishment of the School Counseling Task Force.

Current Status of the Specialty Area

From these types of efforts, as well as from continued dialogue and discussion among school counselors, counselor educators, and counselor supervisors, a reconceptualization of the specialty area has occurred. Currently, the appropriate focus for school counseling is considered to be on comprehensive and developmental programs. Such programs include individual, small- 
group, and large-group counseling as well as consultation and coordination. These programs still offer certain types of responsive services related to remediation and crisis intervention, but they now emphasize primary prevention and the promotion of healthy development for all students. Descriptions of and rationale for such developmental programs are readily available in the professional literature (e.g., ASCA position and role statements; The School Counselor; Elementary School Guidance Counseling; Borders \& Drury, 1992a, 1992b; Gysbers \& Henderson, 1994; Myrick, 1987; Paisley \& Hubbard, 1994; Perry \& Schwallie-Giddis, 1993; Vernon \& Strub, 1990-1991; Wittmer, 1993).

The focus on comprehensive and developmental programs is well-supported from research as well as from the wisdom of practice. It is unlikely, however, that the dialogue or debate concerning this specialty area is complete. The discussion will continue to be a dynamic one as the needs of children and adolescents change and as counselors understand more about the most effective interventions.

\section{SPECIALTY TRAINING STANDARDS AND ACCREDITATION}

A number of accrediting bodies have standards for counselor education programs, including those that train school counselors. Many programs are currently evaluated by up to four such groups: Council for Accreditation of Counseling and Related Educational Programs (CACREP), National Council for the Accreditation of Teacher Education (NCATE), various state departments of education, and university graduate schools.

The accrediting body most closely allied with the profession and most reflective of the "best" knowledge and skills as related specifically to school counseling is CACREP. School counseling is one of six specialty program areas for which CACREP currently makes accreditation decisions. This means that in addition to common core curricular experiences expected for counselor education students, other courses and practica are expected specifically for school counseling graduate students (e.g., foundations, contextual dimensions, knowledge and skills, and clinical instruction; see the CACREP Accreditation Standards and Procedures Manual, Council for Accreditation of Counseling and Related Educational Programs, 1994). These CACREP standards represent the most rigorous regulating guidelines for school counseling preparation programs and acknowledge the recognition of the specialty area by the profession. Currently, 76 school counseling preparation programs are accredited by CACREP.

The majority of school counseling preparation programs, however, currently are not accredited by CACREP (Hollis \& Wantz, 1993). Instead, most are regulated through their state departments of education or as part of a unit evaluation conducted by NCATE. NCATE does recognize CACREP as the accrediting body for counseling programs and therefore does not require the preparation of separate folios for NCATE review. NCATE, however, is not actually accrediting specific programs but is interested in the college or school of education as a unit. Many states use a review process that combines NCATE unit review with state department of education program 
evaluation. Standards used in program review vary from state to state. Some states, however, have used CACREP standards in determining their own guidelines (Paisley \& Hubbard, 1989).

\section{SPECIALTY CERTIFICATION}

School counselors were the first to have a specialty credential (Clawson, 1993) by means of requirements for certification in each state. Although each state has such a process in place for school counselors, the requirements for certification vary greatly (e.g., teaching experience, coursework and practica, provisional employment; Paisley \& Hubbard, 1989).

Although the state certification process has been in place for many years, the first national credential did not occur until 1992, when the National Certified School Counselor (NCSC) credential became effective. This credential was the result of joint efforts among the National Board of Certified Counselors (NBCC), which administers the NCSC certificate, ASCA, and ACA. As of June 1, 1994, 674 NCSCs had been certified by NBCC. Applicants to the NCSC credential must first meet requirements for the generic National Certified Counselor (NCC) credential and then complete specialized coursework and additional experiences specific to school counseling.

A national specialty certification for school counselors is a significant professional statement for several reasons. Perhaps most important, the certification is based on national standards rather than "state edicts" (Clawson, 1993, p. 264). Although national standards have been in existence for some time through ASCA position statements, the national credential more formally acknowledges the school counseling profession's rights and responsibilities to define the role of school counselors and to set standards for training, continuing education, and ethical practice.

Second, the specialty certification may become an alternative method for gaining state certification and, eventually, the basis for more cooperative and efficient reciprocal agreements between state certification boards (Clawson, 1993). Such state recognition, which is a high priority goal for NBCC (T. Clawson, personal communication, November 1, 1993), would benefit both school counselors and the profession.

\section{FUTURE TRENDS AND ISSUES}

Discussions of the future of school counseling are often focused on demographic, economic, and social trends that will affect the profile of tomorrow's students, their families, and the structure of schools (e.g., Commission on Precollege Guidance and Counseling, 1986; Hodgkinson, 1985). School counselors must prepare themselves to deal with increasing numbers of single-parent and low-income families, women in the workforce, and students from minority and immigrant groups; greater use of technology in schools and the workplace; more frequent career changes; and increasing violence in schools, families, and communities. Relevant changes in the counseling program and the counselor's workday will be necessary. In addition, calls for program evaluation and accountability are loud and clear (see Borders \& Drury, 1992a, 1992b). Rather 
than repeat these important discussions, however, we would like to focus on several more basic issues that are central to the profession's functioning and survival.

\section{Control Over the Profession}

Perhaps the most overriding issue for the school counseling specialty is the lack of control school counselors have over their day-to-day work activities and the development of their profession. The school counselor's role continues to be either explicitly or implicitly defined (if not dictated) by a number of sources, few of whom have any background or experience in school counseling and who often provide somewhat contradictory direction. School counselors, for example, are directly accountable to school principals and the school system's director of school counseling. Unfortunately, many times these individuals do not have a counseling background. If that is the case, these two noncounseling "supervisors" may have very different agendas about the counselor's role in a school. In addition, these administrators (sometimes unknowingly) may make requests that school counselors consider unethical, such as requests for program evaluation reports that include lists of clients' names and their reasons for seeing the counselor.

School counselors also are affected by state and federal legislation about, and funding for, the provision of counseling services in the schools. Such legislation often has positive effects, such as those previously noted as related to the National Defense Education Act. Some legislation, however, has adverse effects, sometimes negatively redefining the school counselor's role. In recent years, for example, part-time employees have been hired with federal funds for specialized counseling work (e.g., dropout prevention, substance abuse). School counselors often have pleaded that the additional funds be used to hire another school counselor so that studentcounselor ratios could be lowered and school counselors would have more time to attend to the special needs highlighted by the funding sources. Usually, these pleas have been to little avail, and school counselors have watched part-time employees provide direct counseling services that they themselves are trained to provide and would like to offer. This situation is particularly troublesome when the part-time employee is not qualified. In addition, funding specifications too often have included narrow definitions (e.g., financial brackets, personal characteristics) of who may be served by the part-time employees. As a result, some students are "ineligible" to receive the services they need.

Relatedly, it sometimes seems that school counselors are functioning in some no-(wo)man's land, in that educational administrators, legislators, school reformers, and others think almost exclusively of teachers when making decisions about schools. It often appears that school counselors are completely overlooked by these persons; at best, they are misunderstood. School counselors, in many cases, have been left out of the current reform movement (Herr, 1984), although both ASCA and ACES are attempting to become more actively involved in this process. Many of the skills needed in addressing reform issues, as well as in facilitating the process for change, are skills that school counselors already have (Perry \& Schwallie-Giddis, 1993). To be viable contributors to this movement, however, school counselors and counselor 
educators and supervisors will have to be assertive in their attempts to become involved at both the national and local level.

\section{School Counselor Role}

The lack of control over one's professional life and destiny probably contributes a great deal to a second fundamental issue: the ongoing confusion and controversy about the appropriate focus for its practitioners. The discussion, and arguments, about a school counselor's role continues despite a series of ASCA statements; task force reports; published surveys of counselors, principals, teachers, and parents; and countless other articles and presentations at state and national meetings. A number of role-related questions continue to be debated, such as "To what extent should school counselors be in the classroom?" and "What percentage of a school counselor's time should be devoted to direct services, and what percentage to administrative tasks?"

Philosophical Questions

There are two more philosophical questions about the role of school counselors. The first concerns their role in the delivery of a comprehensive developmental program. Such a program is often cited as the very foundation for the role of a counselor in the schools. Despite its centrality to the profession, however, such a program has rarely been implemented; instead, scope and sequence have been confused with a theoretically based approach using what is known about development and how it occurs (Gerler, 1992; Paisley \& Hubbard, 1994). If school counseling retains the emphasis on developmental programs, then the challenge for professionals in this area is to clearly define the concept and translate these ideas to practice.

The second philosophical role question being (sometimes hotly) debated is, "What is counseling in the schools?" A frequent response to this question is, "School counselors don't do therapy." The distinction between counseling and therapy is never clear, and it often seems to have little relevance. Every semester, our school counseling interns or their site supervisors lament that they cannot do "real counseling" in the schools; one recently complained that her system had a limit of six to eight sessions with a student. Although we do not want to gloss over the frequent need to refer students for long-term therapeutic work, recent literature on brief counseling (see Steenbarger, 1992, for a review) has much relevance for school counselors. Brief counseling models are not only a reactive response to those situations in which a counselor has only six to eight sessions with a student or client. (The limited number of sessions is now common across settings.) Brief models also are built on research indicating that a counselor's most effective work may be accomplished in the first eight sessions (e.g., Whiston \& Sexton, 1993). Several writers have proposed ways to apply brief models in the school setting (e.g., Amatea \& Lochausen, 1988; Littrell et al., 1992). Thus, training in brief models may offer one critical avenue to helping school counselors more effectively provide "real counseling" to their students.

Perhaps the most visible discussion about the "what is counseling?" question can be found in the proliferation of writings proposing that school counselors provide family counseling (e.g., 
Golden, 1983; Hinkle, 1993; Nicoll, 1992; Peeks, 1993; Walsh \& Giblin, 1988). Advocates of family counseling in the schools note the unarguable contribution that parents and family problems often make to students' in-school problems and cite research supporting the effectiveness of family interventions in improving students' academic and behavioral problems. Opponents point to the already overwhelming list of tasks and responsibilities assigned to school counselors and ask which of these family counseling is to replace. We must confess that we as individuals hold divergent views on the appropriateness of family counseling in the schools, and thus we cannot provide one recommendation. We have both noted, however, that some descriptions of family counseling in the schools are quite similar to descriptions of consultation with parents, a function that has been a part of the school counselor's role for some time. It may be that adapting and applying principles and techniques from family counseling actually will serve primarily to enhance the consulting role. However the question about family counseling is answered, it is a critical one in light of predictions that schools of the future will function as "family centers" that offer a wide variety of family services, from medical clinics to satellite counseling and from recreation centers to retraining career programs for adults (Cetron, 1985). It is clear, on the basis of demographic, social, and economic trends, that working with parents in some capacity will become an increasingly important aspect of the school counselor's work.

\section{Supervision}

However counseling in the school is defined and whatever parameters are in effect, it is clear that school counselors are faced with an array of student problems. Given the nature of their work setting, school counselors find themselves on the front lines, sometimes all alone, as viable referral services may not be available or acceptable to the student and his or her family. Thus, like practicing counselors in all work settings, school counselors need the support of ongoing clinical supervision from a qualified counseling supervisor. There is ample evidence that such supervision is not being provided in the schools and that it is a high priority for school counselors (e.g., Borders \& Usher, 1992; Roberts \& Borders, 1994). Most school systems currently do not have qualified supervisors on staff, and there is reason to speculate that clinical supervision is not a high priority for administrators. Innovative programs, such as those described by Benshoff and Paisley (in press) and Henderson and Lampe (1992), are needed to meet this critical need.

\section{SUMMARY}

It is clear that much work and many challenges remain for school counselors. Despite their many successes, it often seems to us that school counselors too frequently find themselves in a reacting role, using all their energy trying to respond to daily challenges and external demands. Thus, little time and energy is left to be innovative or to think creatively about the role of the counselor in tomorrow's schools. We applaud a recent ASCA President's suggestions that school counselors become catalysts for change who are proactive rather than reactive, communicators advocating 
for themselves, caregivers for self and others, and collaborators in providing the best and most appropriate services for children and adolescents (Allen, 1993).

\section{References}

Allen, J. M. (1993). The professional school counselor: Facilitator of decision-making and change agent. Unpublished manuscript.

Amatea, E. S., \& Lochausen, L. (1988). Brief strategic intervention: A new approach to school counseling practice. Elementary School Guidance and Counseling, 23, 39-47.

American School Counselor Association. (1981). The practice of guidance and counseling by school counselors. The School Counselor, 29, 7-12.

American School Counselor Association. (1984). The school counselor and developmental guidance. Alexandria, VA: Author.

American School Counselor Association. (1985). The role of the school counselor in career guidance: Expectations and responsibilities. The School Counselor, 32, 164-168.

Baker, S. B. (1992). School counseling for the twenty-first century. New York: Macmillan.

Benshoff, J. M., \& Paisley, P. O. (in press). A structured peer consultation model for school counselors. Journal of Counseling \& Development.

Borders, L. D., \& Drury, S. M. (1992a). Comprehensive school counseling programs: A review for policymakers and practitioners. Journal of Counseling \& Development, 70, 487-498.

Borders, L. D., \& Drury, S. M. (1992b). Counseling programs: A guide to evaluation. Newbury Park, CA: Corwin.

Borders, L. D., \& Usher, C. H. (1992). Post-degree supervision: Existing and preferred practices. Journal of Counseling \& Development, 70, 594-599.

Cetron, M. J. (1985). Schools of the future: How American business and education can cooperate to save our schools. New York: McGraw-Hill.

Clawson, T. (1993). The school counselor and credentialing. In J. Wittmer (Ed.), Managing your school counseling program (pp. 262-267). Minneapolis, MN: Educational Media Corporation.

Commission on Precollege Guidance and Counseling. (1986). Keeping the options open:

Recommendations. New York: College Entrance Examination Board.

Council for Accreditation of Counseling and Related Educational Programs. (1994). CACREP accreditation standards and procedures manual. Alexandria, VA: Author. 
Gerler, E. (1992). What we know about school counseling: A reaction to Borders and Drury. Journal of Counseling \& Development, 70, 499-501.

Glosoff, H. L., \& Koprowicz, C. L. (1990). Children achieving potential: An introduction to elementary school counseling and state-level policies. Alexandria, VA: American Counseling Association.

Golden, L. (1983). Brief family interventions in a school setting. Elementary School Guidance and Counseling, 17, 288-293.

Gysbers, N. C., \& Henderson, P. (1994). Developing and managing your school guidance program. Alexandria, VA: American Counseling Association.

Henderson, P., \& Lampe, R. E. (1992). Clinical supervision of school counselors. The School Counselor, 39, 151-157.

Herr, E. L. (1984). The national reports on reform in schooling: Some missing ingredients. Journal of Counseling \& Development, 63, 217-220.

Hinkle, J. S. (1993). Training school counselors to do family counseling. Elementary School Guidance and Counseling, 27, 252-257.

Hodgkinson, H. (1985). All one system: Demographics of education, kindergarten through graduate school. Washington, DC: Institute for Educational Leadership.

Hollis, J. W., \& Wantz, R. A. (1993). Counselor preparation 1993-1995. Muncie, IN: Accelerated Development.

Littrell, J. M., Malia, J. A., Nichols, R., Olson, J., Nesselhuf, D., \& Crandell, P. (1992). Brief counseling: Helping counselors adopt an innovative counseling approach. The School Counselor, 39, 171-175.

Minkoff, H. B., \& Terres, C. K. (1985). ASCA perspectives: Past, present, and future. Journal of Counseling \& Development, 63, 424-427.

Myrick, R. D. (1987). Developmental guidance and counseling: A practical approach. Minneapolis, MN: Educational Media.

Nicoll, W. G. (1992). A family counseling and consultation model for school counselors. The School Counselor, 39, 351-361.

Paisley, P. O., \& Hubbard, G. T. (1989). School counseling: State officials' perceptions of certification and employment trends. Counselor Education and Supervision, 29, 60-70.

Paisley, P. O., \& Hubbard, G. T. (1494). Developmental school counseling programs: From theory to practice. Alexandria, VA: American Counseling Association. 
Peeks, B. (1993). Resolution in counseling and education: A systems perspective in the schools. Elementary School Guidance and Counseling, 27, 245-251.

Perry, N. S., \& Schwallie-Giddis, P. (1993). The counselor and reform in tomorrow's schools. Counseling and Human Development, 25(7), 1-8.

Roberts, E. B., \& Borders, L. D. (1994). Supervision of school counselors: Administrative, program, and counseling. The School Counselor, 41, 149-157.

Schmidt, J. J. (1993). Counseling in schools: Essential services and comprehensive programs. Needham Heights, MA: Allyn \& Bacon.

Steenbarger, B. N. (1992). Toward science-practice integration in brief counseling and therapy. Counseling Psychologist, 20, 403-450.

Vernon, A., \& Strub, R. (1990-1991). Developmental guidance program implementation. Cedar Falls: University of Northern Iowa.

Walsh, W. M., \& Giblin, N. J. (Eds.). (1988). Family counseling in school settings. Springfield, IL: Charles C Thomas.

Whiston, S. C., \& Sexton, T. L. (1993). An overview of psychotherapy outcome research: Implications for practice. Professional Psychology, 24, 43-51.

Wittmer, J. (Ed.). (1993). Managing your school counseling program: K-12 developmental strategies. Minneapolis, MN: Educational Media.

Pamela O. Paisley is the School Counseling Program Coordinator in the Department of Counseling and Human Development Services at the University of Georgia. L. DiAnne Borders is an associate professor at the University of North Carolina at Greensboro. Correspondence regarding this article should be sent to Pamela O. Paisley, Counseling and Human Development Services, 402 Aderhold Hall, University of Georgia, Athens, GA 30602-7142. 